\title{
HUBUNGAN TINGKAT PENDIDIKAN IBU DAN PENDAPATAN KELUARGA DENGAN KEJADIAN STUNTING PADA ANAK USIA 6-59 BULAN
}

\author{
Yesi Nurmalasari ${ }^{1}$, Anggunan ${ }^{2}$, Tya Wihelmia Febriany ${ }^{3}$
1Program Pendidikan Dokter Fakultas Kedokteran Universitas Malahayati, Email : yesinurmalasari.dr@gmail.com
2Program Pendidikan Dokter Fakultas Kedokteran Universitas Malahayati,
Email : anggunandr@gmail.com
${ }^{3}$ Program Pendidikan Dokter Fakultas Kedokteran Universitas Malahayati, Email : Tya@gmail.com

\begin{abstract}
Background: Stunting is a condition of failure to thrive in children under five (infants under five years). In Indonesia, based on the results of the 2013 Riskesdas there were $37.2 \%$ of children under five who were stunted, this increased compared to the results of Riskesdas in 2010 which was $35.6 \%$. There are 100 regencies / cities in Indonesia with the highest stunting incidence and priority handling by the government. And 3 of them are in Lampung Province namely South Lampung 43.01\%, Lampung 43.17\% and Central Lampung 52.68\%.

Purpose: The purpose of this study was to determine the relationship between mother's education level and family income with the incidence of stunting in children age 6-59 month in mataram ilir village, seputih surabaya sub-district.

Methods: This study was an observational analytic study with a cross sectional approach. The sample of this study was 237 children by using Purposive Sampling. Data analysis using chi square test analysis.

Results:There is a relationship between mother's education level and stunting with results which are $O R$ 3.313 (Cl: $1,878-5,848)$ and $p$ ( $P$-value) in the form of 0,000 or $p$ value $<0.05$ and there is a relationship between family income and stunting which are $O R 5,132(\mathrm{Cl}: 2,602-10,121)$ and $p$ ( $P$-value) in the form 0,000 or $p$ value $<0,05$ which are low income families are five time more at risk of stunting compared to high income, and $O R$ $2,255(\mathrm{Cl}: 1,127-4,512)$ and $p$ ( $P$-value) in the form 0,032 or $p$ value $<0,05$ which are middle income families are twice as high as stunting compared to high income.

Conclusion: There is a relationship between mother's education level and family income with the incidence of stunting in children age 6-59 months in Mataram llir Village, Seputih Surabaya sub-district 2019.

Suggestion:In related agencies, it is necessary to improve counseling on nutrition in the growth and development of children, provide training on processing nutritious foods without requiring a lot of costs.
\end{abstract}

Keyword: Stunting, Mother's Education Level, Family Income

\section{ABSTRAK}

Latar Belakang : Stunting adalah kondisi gagal tumbuh pada anak balita (bayi di bawah lima tahun). Di Indonesia, berdasarkan hasil Riskesdas tahun 2013 terdapat $37,2 \%$ balita yang mengalami stunting, hal ini mengalami peningkatan dibandingkan hasil Riskesdas tahun 2010 yaitu sebesar $35,6 \%$. Ada 100 kabupaten/kota di Indonesia yang angka kejadian stuntingnya paling besar dan menjadi prioritas penangannya oleh pemerintah. Dan 3 diantaranya terdapat di Provinsi Lampung yaitu Lampung Selatan 43.01\%, Lampung $43,17 \%$ dan Lampung Tengah $52,68 \%$.

Tujuan : Tujuan dari penelitian ini adalah untuk mengetahui hubungan tingkat pendidikan ibu dan pendapatan keluarga dengan kejadian stunting pada anak usia 6-59 bulan di Desa Mataram llir Kecamatan Seputih Surabaya tahun 2019

Metode : Penelitian ini berbentuk analitik observasional dengan pendekatan cross sectional. Sampel penelitian ini adalah 237 anak usia 6-59 bulan yang didapatkan dari perhitungan purposive Sampling. Analisis data menggunakan uji chi square.

Hasil : Terdapat hubungan antara tingkat pendidikan ibu dengan stunting dengan hasil yaitu nilai $O R$ $3,313(\mathrm{Cl}: 1,878-5,848)$ dan nilai $p(P$-value) berupa 0,000 atau $p$ value $<0,05$ dan terdapat hubungan antara pendapatan keluarga dengan stunting dengan hasil yaitu nilai $\mathrm{OR} 5,132(\mathrm{Cl}: 2,602-10,121)$ dan nilai $p(P$ value) berupa 0,000 atau $p$ value $<0,05$ dimana keluarga dengan pendapatan rendah berisiko lima kali lebih 
tinggi mengalami stunting dibandingkan pendapatan tinggi, dan nilai OR 2,255 $(\mathrm{Cl}: 1,127-4,512)$ dan nilai $p(P$ value) berupa 0,032 atau $p$ value $<0,05$ dimana keluarga dengan pendapatan menengah berisiko dua kali lebih tinggi mengalami stunting dibandingkan pendapatan tinggi.

Kesimpulan :Terdapat hubungan antara tingkat pendidikan ibu dan pendapatan keluarga dengan kejadian stunting pada anak usia 6-59 bulan di Desa Mataram Ilir Kecamatan Seputih Surabaya tahun 2019. Saran: Pada Instansi yang terkait, perlu meningkatkan penyuluhan mengenai gizi dalam pertumbuhan dan perkembangan anak, memberikan pelatihan tentang pengolahan makannan yang bergizi tanpa membutuhkan biaya yang banyak.

Kata kunci : Tingkat Pendidikan Ibu, Pendapatan Keluarga, Stunting

\section{PENDAHALUAN}

Stunting adalah kondisi gagal tumbuh pada anak balita (bayi di bawah lima tahun) akibat dari kekurangan gizi kronis sehingga anak terlalu pendek untuk usianya. Balita pendek (stunted) dan sangat pendek (severely stunted) adalah balita dengan tinggi badan (TB/U) menurut nilai z-score kurang dari $-2 \mathrm{SD} /$ standar deviasi (stunted) dan kurang dari - 3SD (severely stunted) (Kemiskinan, 2017).

Kejadian stunting pada balita merupakan salah satu permasalahan gizi secara global. Berdasarkan data Riskesdas 2018 menunjukkan prevalensi kejadian stunting di dunia mencapai $22,2 \%$ atau sebesar 151 juta (Indonesia, 2018). Bila dibandingkan dengan batas "non public health problem" menurut WHO untuk masalah stunting sebesar $20 \%$, maka hampir seluruh negara di dunia mengalami masalah kesehatan masyarakat (Unicef, 2013 dalam Mitra, 2015).

$\mathrm{Di}$ Indonesia, berdasarkan hasil riset kesehatan dasar (Riskesdas) tahun 2018 terdapat $30,8 \%$ balita yang mengalami stunting dan untuk tingkat provinsi Lampung didapatkan 27,3\%. Angka tersebut melebihi target nasional yaitu 20\% (Indonesia, 2018). Ada 100 kabupaten/kota di Indonesia yang angka kejadian stuntingnya paling besar dan menjadi prioritas penangannya oleh pemerintah. Dan 3 diantaranya terdapat di Provinsi Lampung yaitu Lampung Selatan $43.01 \%$, Lampung $43,17 \%$ dan Lampung Tengah 52,68\%. (Kemiskinan, 2017).

Ada beberapa faktor yang mempengaruhi terjadinya stunting pada anak yakni faktor langsung dan tidak langsung. Salah satu faktor tidak langsung yaitu tingkat pendidikan ibu dan pendapatan keluarga. Menurut Soekirman dan UNICEF bahwa status gizi rendah secara langsung dapat dipengaruhi oleh asupan zat gizi yang rendah. Asupan gizi rendah dapat disebabkan ketersediaan pangan tingkat rumah tangga yang tidak cukup. Ketersediaan pangan ini akan terpenuhi, jika daya beli masyarakat cukup. Sosial ekonomi masyarakat merupakan faktor yang turut berperan dalam menentukan daya beli keluarga, keluarga dengan pendapatan yang tinggi akan lebih mudah memperoleh akses pendidikan dan kesehatan sehingga status gizi anak dapat lebih baik (Rahma\& Nadhiroh 2017; Putri, Rahayu \& Maemunah 2017).

Salah satu parameter untuk menentukan sosial ekonomi keluarga adalah tingkat pendidikan, tingkat pendidikan dapat memudahkan seseorang atau masyarakat untuk menyerap informasi dan menerapkannya dalam perilaku hidup sehari-hari. Terutama tingkat pendidikan pengasuh anak. Pendidikan dan pengetahuan ibu rendah akibatnya ia tidak mampu untuk memilih hingga menyajikan makanan untuk keluarga memenuhi syarat gizi seimbang. Hal ini senada dengan hasil penelitian di Meksiko bahwa pendidikan ibu sangat penting dalam hubungannya dengan pengetahuan gizi dan pemenuhan gizi keluarga khususnya anak, karena ibu dengan pendidikan rendah antara lain akan sulit menyerap informasi gizi sehingga anak dapat berisiko mengalami stunting (Soekirman, 2000 dalam Rahayu dkk, 2014).

\section{METODE}

Penelitian ini merupakan penelitian analitik observasional dengan pendekatan cross sectional. Penelitian ini dilakukan di Desa Mataram Ilir Kecamatan Seputih Surabaya Kabupaten Lampung Tengah pada bulan Februari 2019. Sampel penelitian berjumlah 237 balita. Teknik pengumpulan data mengggunakan quesioner Analisis data menggunakan uji statistik Chi square untuk menguji signifikansi antar variabel. Tingkat signifikansi hasil uji $p<0.05$.

\section{HASIL DAN PEMBAHASAN}

Penelitian ini dilaksanakan pada bulan Februari 2019. Tempat penelitian di Desa Mataram llir Kecamatan Seputih Surabaya Lampung Tengah. Sampel pada penelitian ini berjumlah 237 balita. 
Tabel 1.

Karakteristik balita berdasarkan jenis kelamin

\begin{tabular}{ccc}
\hline Jenis Kelamin & Frekuensi & $\begin{array}{c}\text { Persentase } \\
(\%)\end{array}$ \\
\hline $\begin{array}{c}\text { Perempuan } \\
\text { Laki-laki }\end{array}$ & 130 & $54,9 \%$ \\
\hline Total & 107 & $45,1 \%$ \\
\hline Usia & Frekuensi & $\begin{array}{c}\text { Persentase } \\
(\%)\end{array}$ \\
\hline 6-12 Bulan & 27 & $11,4 \%$ \\
13-24 Bulan & 52 & $21,9 \%$ \\
25-36 Bulan & 73 & $30,8 \%$ \\
37-48 Bulan & 21 & $8,9 \%$ \\
49-59 Bulan & 64 & $27 \%$ \\
\hline Total & 237 & $100 \%$ \\
\hline
\end{tabular}

Berdasarkan tabel 1 di atas dapat diketahui bahwa balita berdasarkan jenis kelamin dalam penelitian ini sebagian besar adalah jenis kelamin perempuan sebanyak

130 balita $(54,9 \%)$ dan balita dengan jenis kelamin laki-laki sebanyak 107 balita (45,1\%), Berdasarkan usia diketahui bahwa usia balita yang paling tinggi dalam penelitian ini yaitu pada usia 25-36 bulan sebanyak 73 balita $(30,8 \%)$. Balita terbanyak selanjutnya adalah pada usia 49-59 bulan sebanyak 64 balita (27\%). Balita dengan usia 13-24 bulan sebanyak 52 balita $(21,9 \%)$. Balita dengan usia 6 12 bulan sebanyak 27 balita $(11,4 \%)$. Selanjutnya, balita dengan usia 37-48 bulan sebanyak 21 balita $(8,9 \%)$.

Tabel 2.

Distribusi Frekuensi Responden Berdasarkan Kejadian Stunting

\begin{tabular}{ccc}
\hline Kejadian Stunting & Frekuensi & $\begin{array}{c}\text { Persentase } \\
(\%)\end{array}$ \\
\hline Stunting & 96 & $40,5 \%$ \\
Normal & 141 & $59,5 \%$ \\
\hline Total & 237 & $100 \%$ \\
\hline Tingkat pendidikan lbu & Frekuensi & $\begin{array}{c}\text { Persentase } \\
(\%)\end{array}$ \\
\hline Pendidikan Rendah & 139 & $58,6 \%$ \\
Pendidikan Tinggi & 98 & $41,4 \%$ \\
\hline Total & 237 & $100 \%$ \\
\hline Pendapatan Keluarga & Frekuensi & Persentase \\
& & $(\%)$ \\
\hline Pendapatan Rendah & 80 & $33,8 \%$ \\
Pendapatan Menegah & 73 & $30,8 \%$ \\
Pendapatan Tinggi & 84 & $35,4 \%$ \\
\hline Total & 237 & $100 \%$ \\
\hline
\end{tabular}

Berdasarkan tabel 2 diketahui bahwa balita di Desa Mataram llir Kecamatan Seputih Surabaya
Lampung Tengah normal ( $\geq-2$ SD) sebanyak 141 balita $(59,5 \%)$, dan stunting sebanyak 96 balita $(40,5 \%)$.

Stunting merupakan masalah kurang gizi kronis yang disebabkan oleh asupan gizi yang kurang dalam waktu cukup lama akibat pemberian makanan yang tidak sesuai dengan kebutuhan gizi. Stunting terjadi mulai janin masih dalam kandungan dan baru nampak saat anak berusia dua tahun (Djauhari, 2017).

Dampak yang diakibatkan oleh stunting menurut WHO terbagi menjadi dua yaitu jangka pendek dan jangka panjang. Dampak jangka pendek diantaranya dapat menyebabkan peningkatan mortalitas dan morbiditas, di bidang perkembangan berupa penurunan kognitif, motorik, dan bahasa pada balita, dan di bidang ekonomi berupa peningkatan pengeluaran biaya kesehatan. Stunting juga dapat menyebabkan dampak jangka panjang di bidang kesehatan berupa perawakan pendek, peningkatan risiko obesitas. ( Sudargo, Freitag, Kusmayanti \& Rosiyanti 2018). Pendidikan ibu dapat diketahui bahwa tingkat pendidikan ibu di Desa Mataram Ilir Kecamatan Seputih Surabaya Lampung Tengah tingkat pendidikan ibu sebanyak $139(58,6 \%)$ responden dengan pendidikan rendah dan $98(41,4 \%)$ responden dengan pendidikan tinggi.

Pendidikan adalah usaha dan terencana untuk mewujudkan suasana belajar dan proses pembelajaran agar peserta didik secara aktif mengembangkan potensi dirinya untuk memiliki kekuatan spiritual keagamaan, serta keterampilan yang diperlukan dirinya, masyarakat, bangsa dan negara (Hardini, 2017). Umumnya ibu dengan pendidikan tinggi mempunyai pengetahuan yang lebih luas tentang praktik perawatan anak serta mampu menjaga dan merawat lingkungannya agar tetap bersih. Orang tua terutama ibu yang mendapatkan pendidikan lebih tinggi dapat melakukan perawatan anak dengan lebih baik daripada orang tua dengan pendidikan rendah (Ikeda, et al., 2013 dalam Ni'mah dkk, 2015).

Tingkat pendapatan dapat diketahui bahwa pendapatan keluarga di Desa Mataram Ilir Kecamatan Seputih Surabaya Lampung Tengah pendapatan keluarga sebanyak $80 \quad(33,8 \%)$ responden dengan pendapatan rendah, $73(30,8 \%)$ responden dengan pendapatan menengah dan 84 $(35,4 \%)$ responden dengan pendapatan tinggi.

Pendapatan adalah hasil pencarian atau perolehan dari usaha dan bekerja. Pendapatan merupakan jumlah penghasilan yang diterima seseorang baik berupa uang atau barang yang 
merupakan hasil dari kerja atau usaha (Astuti, 2013 dalam Farhan, 2017).

Kemampuan ekonomi merupakan salah satu faktor penting yang menggambarkan daya beli masyarakat terhadap kebutuhannya, terutama kebutuhan pangan yang cukup dan aman. Rendahnya ketersediaan pangan, mengancam penurunan konsumsi makanan yang beragam, bergizi seimbang dan aman di tingkat rumah tangga. ketersediaan pangan yang rendah mampu meningkatkan risiko menghasilkan anak yang stunting dibandingkan dengan ketersediaan pangan keluarga yang baik (Ulfani, 2011 dalam Bening, 2016).

Tabel 3.

Hubungan Tingkat Pendidikan Ibu dengan Kejadian Stunting

\begin{tabular}{|c|c|c|c|c|c|c|c|c|}
\hline \multirow{3}{*}{ Tingkat Pendidikan Ibu } & \multicolumn{4}{|c|}{ Kejadian Stunting } & \multirow{2}{*}{\multicolumn{2}{|c|}{ Total }} & \multirow{3}{*}{$P$ value } & \multirow{3}{*}{$\begin{array}{c}\text { OR } \\
\text { (Cl 95\%) }\end{array}$} \\
\hline & \multicolumn{2}{|c|}{ Normal } & \multicolumn{2}{|c|}{ Stunting } & & & & \\
\hline & $\mathrm{N}$ & $\%$ & $\mathrm{~N}$ & $\%$ & $\mathrm{~N}$ & $\%$ & & \\
\hline Pendidikan Rendah & 67 & $48,2 \%$ & 72 & $51,8 \%$ & 139 & $100 \%$ & & 3,313 \\
\hline Pendidikan Tinggi & 74 & $75,5 \%$ & 24 & $24,5 \%$ & 98 & $100 \%$ & 0,000 & $(1,878-5,848)$ \\
\hline Total & 141 & 59,5 & 96 & 40,5 & 237 & 100 & & \\
\hline
\end{tabular}

Berdasarkan tabel 3 bahwa diketahui tingkat pendidikan rendah sebanyak $72(51,8 \%)$ responden memiliki anak balita dengan tinggi badan <-2SD (stunting) dan sebanyak $67 \quad(48,2 \%)$ responden yang memiliki anak dengan tinggi badan normal. Sedangkan pada kelompok responden dengan tingkat pendidikan tinggi didapatkan hasil yaitu sebanyak $24(24,5 \%)$ responden memiliki anak dengan tinggi badan <-2SD (stunting) dan sebanyak $74(75,5 \%)$ responden yang memiliki anak dengan tinggi badan normal. Hasil uji statistik didapatkan nilai $p$-value $=0,000(p<0,05)$ yang artinya secara statistik terdapat hubungan yang bermakna antara tingkat pendidikan ibu dengan kejadian stunting dengan kejadian stunting pada anak usia 6-59 bulan di Desa Mataram llir Kecamatan Seputih Surabaya Lampung Tengah. Kemudian diperoleh nilai OR $=3,313(95 \% \mathrm{Cl}$ : $1,878-5,848)$ yang berarti bahwa pendidikan ibu yang rendah berisiko 3,313 kali lebih tinggi untuk mengalami stunting (<-2SD) dibandingkan dengan ibu dengan pendidikan tinggi.

Masa antara kehamilan/janin hingga dua tahun pertama kehidupan anak adalah masa kritis, disebabkan karena pada masa ini kebutuhan gizi pada kelompok ini paling tinggi. Padahal kelompok ini kelompok yang paling rawan memperoleh pola asuh yang salah, akses pelayanan kesehatan yang tidak cukup dan pola pemberian makan yang tidak tepat (Nadiyah dkk, 2014).

Stunting adalah masalah kurang gizi kronis yang disebabkan oleh asupan gizi yang kurang dalam waktu cukup lama akibat pemberian makanan yang tidak sesuai dengan kebutuhan gizi. Kekurangan gizi pada anak usia dini meningkatkan angka kematian bayi dan anak, menyebabkan penderitanya mudah sakit dan memiliki postur tubuh tak maksimal saat dewasa (Millenium Challenga Account Indonesia, 2014 dalam Indrawati, 2016).

Diantara banyaknya faktor risiko terjadinya stunting, pola makan yang buruk, kemiskinan, tinggi badan ibu yang pendek, berat badan ibu yang kurang dan tingkat pendidikan ibu yang rendah adalah lima faktor yang memiliki kontribusi relatif besar terhadap kejadian stunting. Dari faktor tersebut, salah satunya adalah tingkat pendidikan ibu yang rendah.

Tingkat pendidikan terutama tingkat pendidikan ibu memiliki pengaruh terhadap kesehatan keluarganya, salah satunya adalah status gizi dari anggota keluarga. Pendidikan ibu juga mempengaruhi pola asuh pada anak, karena ibu sebagai pembina pertama dan utama terhadap kesehatan anak, pengelola makanan dalam keluarga serta memiliki peranan besar dalam meningkatkan status gizi anggota keluarga (Noviyanti, Rachmawati, \& Sutajo, 2020).

Kejadian stunting pada balita lebih banyak terjadi pada ibu yang berpendidikan rendah. Hal ini dikarenakan di masyarakat masih berkembang pemikiran bahwa pendidikan tidak penting serta terkait dukungan dari keluarga untuk menempuh pendidikan yang lebih tinggi yang masih belum maksimal. Secara tidak langsung tingkat pendidikan ibu akan mempengaruhi kemampuan dan pengetahuan ibu mengenai perawatan kesehatan terutama dalam memahami pengetahuan mengenai gizi. Hal ini juga menyebabkan kurangnya kemampuan ibu dalam memilih makanan dengan harga yang murah dengan nilai gizi yang seimbang dan berkualitas, karena makanan yang memilki nilai gizi baik dan berkualitas tidak harus didapatkan dari makanan yang mahal, banyak makanan dengan harga yang murah memiliki kualitas dan nilai gizi 
yang baik yang dibutuhkan oleh tubuh (Subarkah, Nursalam, Rachmawati, 2019).

Hasil penelitian ini sejalan dengan hasil penelitian Setiawan (2019) yang berjudul FaktorFaktor yang Berhubungan dengan Kejadian Stunting pada Anak Usia 24-59 Bulan di Wilayah
Kerja Puskesmas Andalas Kecamatan Padang Timur Kota Padang Tahun 2019 di Padang yang menunjukkan adanya hubungan yang signifikan antara tingkat pendidikan ibu dengan stunting dengan P-value: 0,012 dan OR sebesar 9,9 (95\% Cl: $1,2-80,5)$.

Tabel 4.

Hubungan Pendapatan Keluarga dengan Kejadian Stunting

\begin{tabular}{|c|c|c|c|c|c|c|c|c|}
\hline \multirow{3}{*}{ Pendapatan Keluarga } & \multicolumn{4}{|c|}{ Kejadian Stunting } & \multirow{2}{*}{\multicolumn{2}{|c|}{ Total }} & \multirow{3}{*}{$P$ value } & \multirow{3}{*}{$\begin{array}{c}\text { OR } \\
(\mathrm{Cl} 95 \%)\end{array}$} \\
\hline & \multicolumn{2}{|c|}{ Normal } & \multicolumn{2}{|c|}{ Stunting } & & & & \\
\hline & $\mathrm{N}$ & $\%$ & $\mathrm{~N}$ & $\%$ & $\mathrm{~N}$ & $\%$ & & \\
\hline Pendapatan Rendah & 32 & $40 \%$ & 48 & $60 \%$ & 80 & $100 \%$ & & \\
\hline Pendapatan Menengah & 44 & $60,3 \%$ & 29 & $39,7 \%$ & 73 & $100 \%$ & 0,000 & 5,13 \\
\hline Pendapatan Tinggi & 65 & $77,4 \%$ & 19 & $22,6 \%$ & 84 & $100 \%$ & & \\
\hline Total & 141 & 59,5 & 96 & 40,5 & 237 & 100 & & \\
\hline
\end{tabular}

Stunting mencerminkan kegagalan dalam mencapai pertumbuhan linier yang potensial sebagai akibat dari adanya status kesehatan atau status gizi. Pertumbuhan linier atau tinggi badan dipengaruhi oleh faktor genetik, faktor lingkungan, dan kondisi medis. Perkembangan dari stunting merupakan proses bertahap dan bersifat kronis, termasuk gizi buruk dan penyakit infeksi, selama periode pertumbuhan linier. Hal ini sering dimulai pada rahim dan meluas melalui dua tahun pertama atau yang biasa disebut 1000 hari pertama pada anak. Tanpa perubahan lingkungan, stunting dapat menyebabkan penurunan pertumbuhan permanen. Dengan demikian, anak-anak yang mengalami stunting pada awal kehidupan seringkali lebih pendek pada masa kanak-kanak dan dewasa dibanding rekannya yang punya pertumbuhan awal yang memadai (Aritonang, hastuti \& Puspitawati, 2020; Yulianti, Arigianti, Herlina \& Oktaviani, 2018).

Pendapatan keluarga berkaitan dengan kemampuan rumah tangga tersebut dalam memenuhi kebutuhan hidup baik primer, sekunder, maupun tersier. Pendapatan keluarga yang tinggi memudahkan dalam memenuhi kebutuhan hidup, sebaliknya pendapatan keluarga yang rendah lebih mengalami kesulitan dalam memenuhi kebutuhan hidup. Pendapatan yang rendah akan mempengaruhi kualitas maupun kuantitas bahan makanan yang dikonsumsi oleh keluarga. Rendahnya tingkat pendapatan dan lemahnya daya beli memungkinkan untuk mengatasi kebiasaan makan dengan cara-cara tertentu yang menghalangi perbaikan gizi yang efektif terutama untuk anak-anak mereka Makanan yang didapat biasanya akan kurang bervariasi dan sedikit jumlahnya terutama pada bahan yang berfungsi untuk pertumbuhan anak sumber protein, vitamin, dan mineral, sehingga meningkatkan risiko kurang gizi. Keterbatasan tersebut akan meningkatkan risiko anggota keluarga mengalami stunting (Hapsari dkk, 2018).

Hasil penelitian ini sejalan dengan hasil penelitian Hapsari (2018) yang berjudul Hubungan Pendapatan Keluarga, Pengetahuan Ibu Tentang Gizi, Tinggi Badan Orang Tua dan Tingkat Pendidikan Ayah Dengan Kejadian Stunting Pada Anak Umur 12-59 Bulan di Kabupaten Boyolali yang menunjukkan adanya hubungan yang signifikan antara pendapatan keluarga dengan kejadian stunting dengan P-value: 0,004.

\section{KESIMPULAN}

Berdasarkan hasil penelitian yang dilakukan dapat diambil kesimpulan sebagai berikut:

Distribusi kejadian stunting pada 237 responden yaitu $96(40,5 \%)$ responden mengalami stunting dan $141(59,5 \%)$ responden normal atau tidak stunting. Distribusi frekuensi tingkat pendidikan ibu pada 237 responden yaitu 139 $(58,6 \%)$ responden berpendidikan rendah dan 98 $(41,4 \%)$ responden berpendidikan tinggi.Distribusi frekuensi pendapatan keluarga pada 237 responden yaitu $80 \quad(33,8 \%)$ responden berpendapatan rendah, $73(30,8 \%)$ responden berpendapatan menengah dan $84 \quad(35,4 \%)$ berpendapatan tinggi. Ada hubungan antara tingkat pendidikan ibu dengan kejadian stunting $(p=0,000)$, $(\mathrm{OR}=3,313)$ pada anak usia 6-59 bulan di Desa Mataram llir Kecamatan Seputih Surabaya Tahun 2019. Ada hubungan antara pendapatan keluarga dengan kejadian stunting pada anak usia 6-59 bulan di Desa Mataram llir Kecamatan Seputih Surabaya Tahun 2019 dengan nilai $(p=0,000)$, $(\mathrm{OR}=5,132)$ dimana responden dengan 
penghasilan rendah berisiko 5,1 lebih tinggi untuk memiliki anak dengan stunting dibandingkan dengan responden berpendapatan tinggi, dan $(p=$ $0,032),(O R=2,255)$ dimana responden dengan pendapatan menengah berisiko 2,2 lebih tinggi untuk memiliki anak dengan stunting dibanding anak dengan responden.

\section{SARAN}

Pada Instansi yang terkait, perlu meningkatkan penyuluhan mengenai gizi dalam pertumbuhan dan perkembangan anak, memberikan pelatihan tentang pengolahan makannan yang bergizi tanpa membutuhkan biaya yang banyak.

\section{DAFTAR PUSTAKA}

Akombi, B., Agho, K., Hall, J., Wali, N., Renzaho, A. and Merom, D., 2017. Stunting, wasting and underweight in sub-Saharan Africa: a systematic review. International journal of environmental research and public health, 14(8), p.863.

Arisman., 2009. Gizi dalam Daur Kehidupan. Jakarta: Buku Kedokteran EGC.

Aridiyah, F.O., Rohmawati, N. and Ririanty, M.,

2015. Faktor-faktor yang Mempengaruhi Kejadian Stunting pada Anak Balita di Wilayah Pedesaan dan Perkotaan (The Factors Affecting Stunting on Toddlers in Rural and Urban Areas). Pustaka Kesehatan, 3(1), pp.163-170.

Aritonang, S.D., Hastuti, D. and Puspitawati, H., 2020. MOTHERING, FATHER INVOLVEMENT IN PARENTING, AND COGNITIVE DEVELOPMENT OF CHILDREN AGED 2-3 YEARS IN THE STUNTING PREVALENCE AREA. Jurnal IImu Keluarga \& Konsumen, 13(1), pp.3848.

Bening, S., Margawati, A. and Rosidi, A., 2018. Asupan Zink, Riwayat ISPA dan Pengeluaran Pangan Sebagai Faktor Resiko Stunting Pada Anak Usia 2-5 tahun di Kota Semarang. Jurnal Gizi, 7(1).

Djauhari, T. 2017. Gizi dan 1000 HPK. Saintika Medika: Jurnal IImu Kesehatan dan Kedokteran Keluarga, 13(2), 125-133.

Farhan, D.A., 2017. Pemberdayaan Kaum Perempuan Guna Meningkatkan Pendapatan Keluarga Dalam Perspektif Ekonomi Islam (Studi pada kelompok wanita tani sekarmulia, Desa Astomulyo, Kecamatan Punggur, Kabupaten Lampung
Tengah). Skripsi. Lampung: UIN Raden Intan Lampung.

Hapsari, W. dan Ichsan, B., 2018. Hubungan Pendapatan Keluarga, Pengetahuan Ibu Tentang Gizi, Tinggi Badan Orang Tua, dan Tingkat Pendidikan Ayah dengan Kejadian Stunting pada Anak Umur 12-59 Bulan. Skripsi. Surakarta : Universitas Muhammadiyah Surakarta.

Hardini, A.T.A., 2017. The Implementation Of Inquiry Method To Increase Students' Participation And Achievement In Learning Social Studies. Scholaria: Jurnal Pendidikan Dan Kebudayaan, 7(2), pp.190198.

Indonesia, K.K.R., 2018. Laporan nasional riset kesehatan dasar 2018. Jakarta: DepKes $\mathrm{Rl}$.

Indrawati, S., 2017. Hubungan Pemberian ASI Eksklusif Dengan Kejadian Stunting Pada Anak Usia 2-3 Tahun Di Desa Karangrejek Wonosari Gunungkidul. skripsi. Yogyakarta : Universitas' Aisyiyah Yogyakarta.

Kemiskinan, T.N.P.P., 2017. 100 kabupaten/kota prioritas untuk intervensi anak kerdil (stunting). Jakarta: Tim Nasional Percepatan Penanggulangan Kemiskinan.

Kusuma, K.E. and Nuryanto, N., 2013. Faktor risiko kejadian stunting pada anak usia 2-3 tahun (Studi di Kecamatan Semarang Timur). Skripsi. Semarang : Diponegoro University.

Mitra, M., 2015. Permasalahan Anak Pendek (Stunting) dan Intervensi untuk Mencegah Terjadinya Stunting (Suatu Kajian Kepustakaan). Jurnal Kesehatan Komunitas, 2(6), pp.254-261.

Nadiyah, N., Briawan, D. and Martianto, D., 2014. Faktor Risiko Stunting Pada Anak Usia 023 Bulan Di Provinsi Bali, Jawa Barat, Dan Nusa Tenggara Timur. Jurnal Gizi dan Pangan, 9(2).

Ni'mah, K., \& Nadhiroh, S.R., 2016. Faktor yang Berhubungan dengan Kejadian Stunting pada Balita. Media Gizi Indonesia, 10(1), pp.13-19.

Noviyanti, L.A., Rachmawati, D.A. and Sutejo, I.R., 2020. An Analysis of Feeding Pattern Factors in Infants at Kencong Public Health Center. JOURNAL AMS, 6(1), pp.14-18.

Putri, R. M., Rahayu, W., \& Maemunah, N. 2017. Kaitan Pendidikan, Pekerjaan Orang Tua dengan Status Gizi Anak Pra Sekolah. Care: Jurnal IImiah IImu Kesehatan, 5(2), 231-245. 
Rahma, A. C., \& Nadhiroh, S. R. 2017.Perbedaan sosial ekonomi dan pengetahuan gizi ibu Balita gizi kurang dan gizi normal. Media Gizi Indonesia, 11(1), 55-60.

Setiawan, Y.A. and Budiana, T.A., 2019. RELATIONSHIP OF MOTHER FACTORS AND STUNTING INCIDENCE IN CHILDREN (24-59 MONTHS) IN BUNIWANGI VILLAGE, WORK AREA OF PAGELARAN PUBLIC HEALTH CENTER, CIANJUR REGENCY, 2018. In The 3rd International Seminar on Global Health (Vol. 3, No. 1, pp. 115-123).

Subarkah, T., Nursalam, N. and Rachmawati, P.D., 2017. Feeding Pattern Toward the
Increasing of Nutritional Status in Children Aged 1-3 Years. INDONESIAN NURSING JOURNAL OF EDUCATION AND CLINIC (INJEC), 1(2), pp.146-154.

Sudargo, T., Freitag, H., Kusmayanti, N.A. and Rosiyani, F., 2018. Pola makan dan obesitas. UGM press.

Yulianti, N., Argianti, P., Herlina, L. and Oktaviani, S.N.I., 2018. ANALYSIS EARLY DETECTION OF GROWTH AND DEVELOPMENT CHILDREN BY PRESCREENING QUESTIONNAIRE OF DEVELOPMENT (KPSP) AT CENTRAL JAKARTA IN OCTOBER 2017. Indonesia Jurnal Kebidanan, 2(1), pp.45-52. 